Article

\title{
Three New Germacrane-Type Sesquiterpenes with NGF-Potentiating Activity from Valeriana officinalis var. latiofolia
}

\author{
Heng-Wen Chen ${ }^{1, \dagger}$, Li Chen ${ }^{1, \dagger}$, Bin Li ${ }^{1}$, Hai-Long Yin ${ }^{1}$, Ying Tian ${ }^{1}$, Qiong Wang ${ }^{1}$, \\ Yan-Hua Xiao ${ }^{1,2}$ and Jun-Xing Dong ${ }^{1, *}$
}

1 Department of Pharmaceutical Chemistry, Beijing Institute of Radiation Medicine, Beijing 100850, China; E-Mails: chenhengwen@163.com (H.-W.C.); chenli7274@126.com (L.C.);

jkYLiBin@hotmail.com (B.L.); yinhailong1983@126.com (H.-L.Y.); Hq6106@gmail.com (Y.T.); wqwangqiongwq@163.com (Q.W.); yanhuaxiao1982@163.com (Y.-H.X.)

2 Institute of Chemical Defense, Beijing 102205, China

$\dagger$ These authors contributed equally to this work.

* Author to whom correspondence should be addressed; E-Mail: dongjx@vip.sina.com; Tel.: +86-10-6821-0077.

Received: 12 October 2013; in revised form: 9 November 2013 / Accepted: 12 November 2013 / Published: 14 November 2013

\begin{abstract}
Three new germacrane-type sesquiterpenoids, volvalerenal F (1), volvalerenal G (2) and volvalerenic acid D (3), along with five known compounds 4-8, were isolated from the $\mathrm{CHCl}_{3}$ soluble partition of the ethanol extract of Valeriana officinalis var. latiofolia. The structures of the new compounds were determined on the basis of spectroscopic evidence, including their 1D- and 2D-NMR spectra, as well as mass spectrometry. The eight germacrane-type sesquiterpenoids showed nerve growth factor (NGF) potentiating activity, which mediates the neurite outgrowth in PC 12D cells. This study intends to reveal the chemical basis of the use of $V$. officinalis var. latiofolia as a dietary supplement.
\end{abstract}

Keywords: Valeriana officinalis var. latiofolia; germacrane-type sesquiterpenes; volvalerenal; volvalerenic acid; PC 12D; NGF-potentiating activity

\section{Introduction}

The genus Valeriana, from the family Valerianaceae, consists of about 250 species widely distributed all over the World. Valeriana is a perennial herb native to Europe, Asia and North 
America [1,2]. Eleven out of 28 Valeriana genus species (including one variant) found in China are traditionally used as medicines. Their dried underground parts (roots and rhizomes) exhibit anodyne, antiphlogistic, expectorant and antiasthmatic activities [3-5].

Valerians have been used clinically as tranquillizers for the treatment of nervousness, agitation and as a mild sedative to improve sleep [6-13]. Previous studies reported that Valeriana contains numerous chemical constituents, including volatile oil, iridoids, flavones, alkaloids, amino acids, and lignans, etc. [14-20]. Valerian (Valeriana officinalis Linn.) has been included in the pharmacopoeias in Europe and the United States [21,22], its extracts are sold as dietary supplements and were listed among the top 10 best-selling herbal supplements in the United States in 2002 [23]. Valerian is also widely used as a precious perfume added into food, drink, cosmetics, tobacco, and so on. With significant medicinal and commercial value, it will surely deserve future development.

$V$. officinalis var. latiofolia, a variant of $V$. officinalis Linn, is produced mainly in the Guizhou, Sichuan and Yunnan provinces in Southwest China. Particularly in Guizhou, V. officinalis var. latiofolia is widely cultivated and has become one of the local industry pillars [1,24]. This variant shares some common pharmaceutical actions and chemical constituents with $V$. officinalis Linn [25]. Abundant research has been done on $V$. officinalis var. latiofolia so far, and it is assumed that the sesquiterpenoids from the volatile oil and iridoids are the main contributors to its antidepressant and antinervousness activities [24,25]. Pairs of active compounds have been isolated and identified from Valeriana, including germacrane-type sesquiterpenoids, volvalerenals $\mathrm{A}-\mathrm{E}$, volvalerenic acids $\mathrm{A}-\mathrm{C}$, valerianin $\mathrm{A}-\mathrm{B}$ and heishuixiecaoline $\mathrm{A}-\mathrm{C}$ [13,16-19]. However, neither the active component(s) responsible for the therapeutic properties of Valeriana nor the related molecular mechanisms are clearly understood, which severely hinders the wider application of Valeriana products. Therefore, in this paper the chemical constituents of $V$. officinalis var. latiofolia have been systematically investigated, and eight germacrane-type sesquiterpenoids (including three new compounds, volvalerenal F (1), volvalerenal G (2) and volvalerenic acid D (3)) were isolated and identified from chloroform extracts of this herb's syrup. Additionally, the NGF-potentiating activities of the obtained products were evaluated.

\section{Results and Discussion}

Volvalerenal F (1) was isolated as a colorless oil. High-resolution mass spectrometry (HR-ESI-MS) $\left(\mathrm{m} / \mathrm{z} 271.1678[\mathrm{M}+\mathrm{Na}]^{+}\right.$, calcd. for $\left.\mathrm{C}_{16} \mathrm{H}_{24} \mathrm{O}_{2} \mathrm{Na}, 271.1669\right)$ of $\mathbf{1}$ indicated that its molecular formula is $\mathrm{C}_{16} \mathrm{H}_{24} \mathrm{O}_{2}$, and together with the NMR data (Table 1), implied five unsaturated degrees in the molecule. The IR spectrum indicated the presence of carbonyl $\left(1730 \mathrm{~cm}^{-1}\right)$ and carbon-carbon double-bond $\left(1627 \mathrm{~cm}^{-1}\right.$ ) absorptions. The ${ }^{1} \mathrm{H}-\mathrm{NMR}$ spectrum of $\mathbf{1}$ (Table 1) displayed three olefinic protons at $\delta_{\mathrm{H}} 5.27$ $(1 \mathrm{H}, \mathrm{dd}, J=5.4,10.2 \mathrm{~Hz}, \mathrm{H}-1), 5.34(1 \mathrm{H}, \mathrm{ddd}, J=9.0,9.0,3.2 \mathrm{~Hz}, \mathrm{H}-4)$, and $5.21(1 \mathrm{H}, \mathrm{dd}, J=9.0,9.0 \mathrm{~Hz}$, $\mathrm{H}-5)$ indicating the presence of two double bonds, methylene proton peaks at $\delta_{\mathrm{H}} 4.42(1 \mathrm{H}, \mathrm{d}, J=12.0 \mathrm{~Hz}$, $\mathrm{H}-14 \mathrm{a})$ and $\delta_{\mathrm{H}} 4.21(1 \mathrm{H}, \mathrm{d}, J=12.0 \mathrm{~Hz}, \mathrm{H}-14 \mathrm{~b})$, and three methyls at $\delta_{\mathrm{H}} 0.98\left(3 \mathrm{H}, \mathrm{s}, 13-\mathrm{CH}_{3}\right), 1.04(3 \mathrm{H}$, s, 12- $\left.\mathrm{CH}_{3}\right)$ and $2.01\left(3 \mathrm{H}, \mathrm{s}, 16-\mathrm{CH}_{3}\right)$. Considering the DEPT spectra, the ${ }^{13} \mathrm{C}-\mathrm{NMR}$ spectrum of $\mathbf{1}$ (Table 1) suggested the existence of an acetate carbonyl carbon at $\delta_{\mathrm{C}} 171.3(\mathrm{C}-15)$, four olefinic carbons at $\delta_{\mathrm{C}} 128.8(\mathrm{C}-1), 133.1(\mathrm{C}-10), 128.3(\mathrm{C}-4)$ and $129.6(\mathrm{C}-5)$, as well as five methylenes at $\delta_{\mathrm{C}} 28.2(\mathrm{C}-2)$, 26.8 (C-3), $23.0(\mathrm{C}-8), 35.3(\mathrm{C}-9)$ and $61.7(\mathrm{C}-14)$, two methines at $\delta_{\mathrm{C}} 26.4(\mathrm{C}-6)$ and $31.9(\mathrm{C}-7)$ and three methyls at $\delta_{\mathrm{C}} 15.6$ (C-13), 21.1 (C-16) and 28.9 (C-12). 
Table 1. ${ }^{1} \mathrm{H}$ and ${ }^{13} \mathrm{C}-\mathrm{NMR}$ Spectroscopic Data of Compounds $\mathbf{1}-\mathbf{3}$.

\begin{tabular}{|c|c|c|c|c|c|c|}
\hline \multirow{2}{*}{ NO. } & \multicolumn{2}{|r|}{1} & \multicolumn{2}{|r|}{2} & \multicolumn{2}{|r|}{3} \\
\hline & $\boldsymbol{\delta}_{\mathrm{C}}$ & $\delta_{\mathrm{H}}$ & $\boldsymbol{\delta}_{\mathrm{C}}$ & $\boldsymbol{\delta}_{\mathrm{H}}$ & $\boldsymbol{\delta}_{\mathrm{C}}$ & $\delta_{\mathrm{H}}$ \\
\hline 1 & 128.8 & $5.27 d d(5.4,10.2)$ & 128.2 & $5.22 d d(5.4,11.4)$ & 130.7 & $5.33 d d(5.4,11.4)$ \\
\hline $2 \mathrm{a}$ & 28.2 & $2.23 m \mathrm{H}-\alpha$ & 28.3 & $2.22 m(\mathrm{H}-\alpha)$ & 29.2 & $2.38 m(\mathrm{H}-\beta)$ \\
\hline $2 b$ & & $2.11 \mathrm{~m} \mathrm{H}-\beta$ & & $2.15 m(\mathrm{H}-\beta)$ & & $2.26 m(\mathrm{H}-\alpha)$ \\
\hline $3 a$ & 26.8 & $2.14 m \mathrm{H}-\beta$ & 24.0 & $2.71 d t(12.0,4.2, \mathrm{H}-\alpha)$ & 27.1 & $2.71 d t(12.6,4.0, \mathrm{H}-\alpha)$ \\
\hline $3 b$ & & $2.08 m \mathrm{H}-\alpha$ & & $2.05 \mathrm{td}(12.6,4.2, \mathrm{H}-\beta)$ & & $2.17 \operatorname{td}(12.6,4.0, \mathrm{H}-\beta)$ \\
\hline 4 & 128.3 & $5.34 d d d(9.0,9.0,3.2)$ & 143.9 & & 132.1 & \\
\hline 5 & 129.6 & $5.21 d d(9.0,9.0)$ & 158.9 & $6.48 d(9.0)$ & 144.8 & $6.72 d(9.6)$ \\
\hline 6 & 26.4 & $1.14 t(9.0, \mathrm{H}-\alpha)$ & 31.2 & $1.52 t(13.2,9.0, \mathrm{H}-\alpha)$ & 30.0 & $1.27 d d(9.6,4.0, \mathrm{H}-\alpha)$ \\
\hline 7 & 31.9 & $0.47 m(\mathrm{H}-\alpha)$ & 38.8 & $1.02 m(\mathrm{H}-\alpha)$ & 36.7 & $0.82 m(\mathrm{H}-\alpha)$ \\
\hline $8 a$ & 23.0 & $1.73 m(\mathrm{H}-\beta)$ & 24.6 & $1.86 m(\mathrm{H}-\beta)$ & 24.7 & $1.81 m(\mathrm{H}-\beta)$ \\
\hline $8 b$ & & $0.76 m(H-\alpha)$ & & $0.90 m(H-\alpha)$ & & $0.89 m(\mathrm{H}-\alpha)$ \\
\hline $9 a$ & 35.3 & $2.39 m(\mathrm{H}-\beta)$ & 35.5 & $2.60 m(\mathrm{H}-\beta)$ & 36.2 & $2.36 m(\mathrm{H}-\beta)$ \\
\hline $9 b$ & & $1.87 t(12.6, \alpha)$ & & $1.88 m(\mathrm{H}-\alpha)$ & & $2.25 m(\mathrm{H}-\alpha)$ \\
\hline 10 & 133.1 & & 139.1 & & 134.3 & \\
\hline 11 & 17.2 & & 22.4 & & 21.5 & \\
\hline 12 & 28.9 & $1.04 \mathrm{~s}$ & 28.7 & $1.16 \mathrm{~s}$ & 28.9 & $1.12 \mathrm{~s}$ \\
\hline 13 & 15.6 & $0.98 s$ & 16.0 & $1.20 \mathrm{~s}$ & 16.1 & $1.14 s$ \\
\hline $14 \mathrm{a}$ & 61.7 & $4.42 d(12.0)$ & 196.4 & $9.20 s$ & 172.9 & \\
\hline $14 b$ & & $4.21 d(12.0)$ & & & & \\
\hline \multirow[t]{2}{*}{15} & 171.3 & & 59.1 & $3.69 d(12.0)$ & 62.8 & $4.32 d(12.0)$ \\
\hline & & & & $3.43 d(12.0)$ & & $4.15 d(12.0)$ \\
\hline 16 & 21.1 & $2.01 \mathrm{~s}$ & & & 172.0 & \\
\hline 17 & & & & & 20.8 & $1.97 \mathrm{~s}$ \\
\hline
\end{tabular}

Compound 1 recorded in $\mathrm{CDCl}_{3}$. Compounds 2 and 3 recorded in $\mathrm{CD}_{3} \mathrm{OD} .{ }^{1} \mathrm{H}-\mathrm{NMR}$ recorded at $600 \mathrm{MHz}$.

${ }^{13} \mathrm{C}-\mathrm{NMR}$ recorded at $150 \mathrm{MHz}$.

To confirm the structure of $\mathbf{1},{ }^{1} \mathrm{H}-{ }^{1} \mathrm{H}$ COSY and HMBC experiments were conducted (Figure 1), which showed the key correlations such as H-1/H-2, H-2/H-3, H-3 (a,b)/H-4, H-4/H-5, H-5/H-6, H-6/H-7, and H-8/H-9 in its COSY, H-14/C-1, H-14/C-9, H-14/C-10, H-14/C-15, H-3/C-4, H-5/C-4 and H-12/C-6, H-12/C-7, H-12/C-11 and H-12/C-13 in its HMBC. The coupling constant of $9.0 \mathrm{~Hz}$ between $\mathrm{H}-4$ and H-5 indicated the Z-configuration of the double bond [26,27]. The coupling constant of $9.0 \mathrm{~Hz}$ and the NOE correlations between H-6 and H-7 suggested the syn and $\alpha$-oriented of the cyclopropane moiety, and the $\alpha$-orientation of H-6 and H-7 were assigned by the correlations of $\mathrm{H}-7 / \mathrm{CH}_{3}-12$ and $\mathrm{H}-6 / \mathrm{CH}_{3}-12$ [28]. The correlations of $\mathrm{H}-2(\mathrm{~b}) / \mathrm{H}-15(\mathrm{a}, \mathrm{b})$ indicated $\Delta^{1,10}$ to be $Z$ configured. From the above data, the structure of $\mathbf{1}$ was identified as 14-acetoxy-11,11-dimethylbicyclo[8.1.0]undeca-4Z (5),10Z (1)-diene, and the compound was named volvalerenal F. 
Figure 1. The correlations of structures, ${ }^{1} \mathrm{H}-{ }^{1} \mathrm{H}$ COSY and Key HMBC of $\mathbf{1}$.

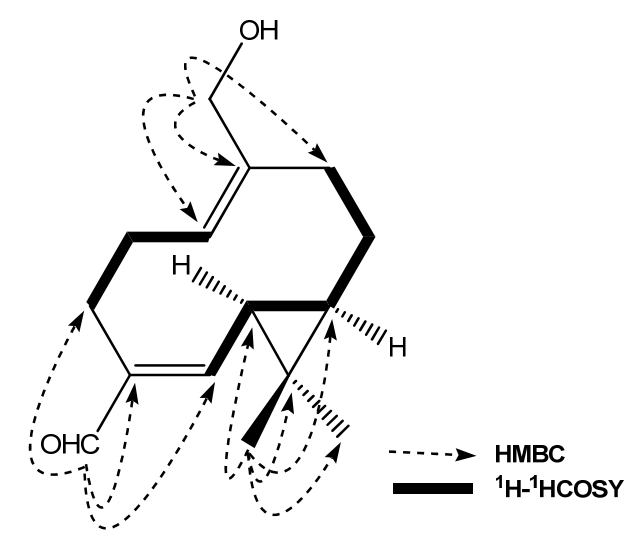

Compound 2 was isolated as a colorless oil. The molecular formula was assigned as $\mathrm{C}_{15} \mathrm{H}_{22} \mathrm{O}_{2}$ on the basis of HR-ESI-MS from the $[\mathrm{M}+\mathrm{H}]^{+}$signal at $\mathrm{m} / z 235.1696$ (calcd. for $\mathrm{C}_{15} \mathrm{H}_{23} \mathrm{O}_{2}, 235.1693$ ), with five degrees of unsaturation. The IR spectra displayed the presence of carbonyl $\left(1726 \mathrm{~cm}^{-1}\right), \alpha, \beta$-unsaturated aldehyde $\left(1678 \mathrm{~cm}^{-1}\right)$, and carbon-carbon double-bond $\left(1626 \mathrm{~cm}^{-1}\right)$ absorptions.

The ${ }^{13} \mathrm{C}$-NMR and DEPT spectra of 2 (Table 1) showed an aldehyde carbon at $\delta_{\mathrm{C}} 196.4$ (C-14), four double bond carbons at $\delta_{\mathrm{C}} 128.2$ (C-1), 143.9 (C-4), 158.9 (C-5) and 139.1 (C-10), as well as five methylenes (one oxygenated) at $\delta_{\mathrm{C}} 24.0(\mathrm{C}-3), 24.6(\mathrm{C}-8), 28.3(\mathrm{C}-2), 35.5(\mathrm{C}-9)$ and $59.1(\mathrm{C}-15)$, two methines at $\delta_{\mathrm{C}} 31.2(\mathrm{C}-6)$ and $38.8(\mathrm{C}-7)$, and two methyls at $\delta_{\mathrm{C}} 16.0(\mathrm{C}-13)$ and $28.7(\mathrm{C}-12)$. These data suggested that compound 2 was also a germacrane-type sesquiterpenoid. Its ${ }^{1} \mathrm{H}-\mathrm{NMR}$ spectrum displayed an aldehydic proton obviously at $\delta_{\mathrm{H}} 9.20(1 \mathrm{H}, \mathrm{s}, \mathrm{H}-14)$, an oxygenated methine proton at $\delta_{\mathrm{H}}$ $3.69(1 \mathrm{H}, \mathrm{d}, J=12.0 \mathrm{~Hz}, \mathrm{H}-15 \mathrm{a})$ and $3.43(1 \mathrm{H}, \mathrm{d}, J=12.0 \mathrm{~Hz}, \mathrm{H}-15 \mathrm{~b})$. Above data indicated 2 was structurally similar to heishuixiecaoline B reported in the literature [13].

The proposed structure was further confirmed by $\mathrm{HMBC}$ correlations (Figure 2). Key long-range correlations were observed between H-12/C-6, H-12/C-7, H-12/C-11, H-12/C-13, H-15/C-1, H-15/C-10, H-15/C-9, and H-14/C4, H-14/C-5, which suggested the aldehyde group and hydroxyl group were located to $\mathrm{C}-4$ and $\mathrm{C}-15$, respectively. The $\alpha$-orientation of $\mathrm{H}-6$ and $\mathrm{H}-7$ were assigned as being the same as those of 1 by the correlations of $\mathrm{H}-6 / \mathrm{H}-7, \mathrm{H}-7 / \mathrm{CH}_{3}-12$ and $\mathrm{H}-6 / \mathrm{CH}_{3}-12$ in the NOESY experiment (Figure 4), and the $E$ - and $Z$ - configurations of $\Delta^{4,5}$ and $\Delta^{1,10}$ were determined to be the same as in compound 1 by the correlations of H-5/H-14, H-2 (a, b)/H-15 and H-5 with H-1.

Figure 2. The correlations of structures, ${ }^{1} \mathrm{H}-{ }^{1} \mathrm{H}$ COSY and Key HMBC of 2.

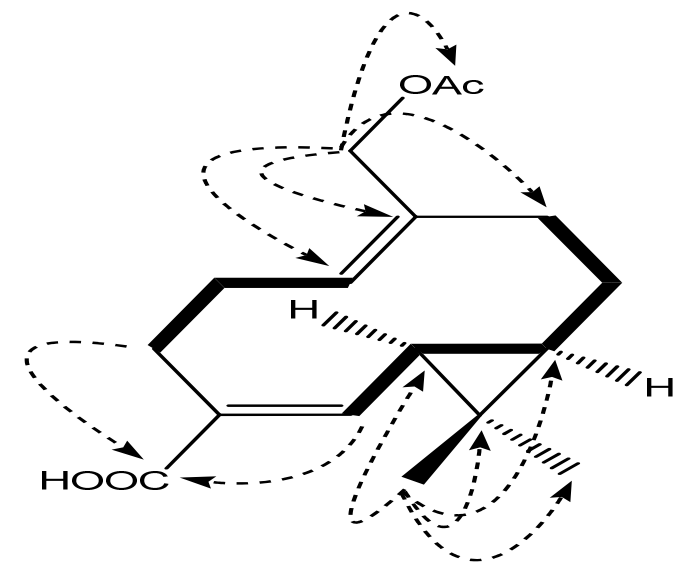


On the basis of the above data, the structure of 2 was identified as 4-formyl-10-hydroxymethyl-11, 11-dimethylbicyclogermacren- $4 E$ (5), $10 Z$ (1)-diene, and the product was named volvalerenal G.

Volvalerenic acid D (3) was also isolated as a colorless oil. The HR-ESI-MS of $\mathbf{3}$ indicated that its molecular formula is $\mathrm{C}_{17} \mathrm{H}_{24} \mathrm{O}_{2}\left(\mathrm{~m} / z 293.1744[\mathrm{M}+\mathrm{H}]^{+}\right.$, calcd. for 293.1747). The IR data was completely similar to that of compound $\mathbf{1}$, which suggested that $\mathbf{3}$ was also a germacrane-type sesquiterpenoid.

The NMR spectrum of compound 3 (Table 1) showed the following signals: an acetate carbonyl carbon, four olefinic carbons, five methylenes (one oxygenated), two methines and three methyls, which were quite similar to those of compound 1. In addition, it is noteworthy that the NMR data displayed an obvious carboxyl carbon signal at $\delta_{\mathrm{C}} 172.0(\mathrm{C}-16)$. The ${ }^{1} \mathrm{H}-{ }^{1} \mathrm{H}$ COSY spectrum showed key correlations such as $\mathrm{H}-6 / \mathrm{H}-7$ and $\mathrm{H}-8 / \mathrm{H}-9$, and key long-range correlations were observed in the HMBC experiments between H-3/C-14 and H-5/C-14 (Figure 3), which suggested the carboxyl group was located to C-4.

Figure 3. The correlations of structures, ${ }^{1} \mathrm{H}-{ }^{1} \mathrm{H}$ COSY and Key HMBC of 3.
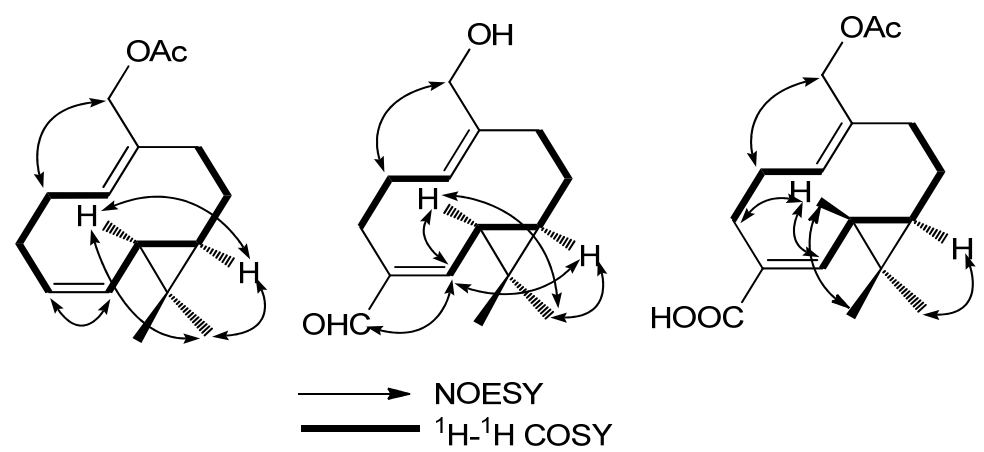

The NOESY correlations (Figure 4), the coupling constant of $4.0 \mathrm{~Hz}$ and the NOE correlations between H-6 and H-7 suggested a trans geometry around the cyclopropane ring, and the correlations of H-6/H-3a, H-2 (a, b)/H-15 suggested the $E$ - and $Z$ - configuration of $\Delta^{4,5}$ and $\Delta^{1,10}$.

Figure 4. NOE correlations of compounds 1-3.

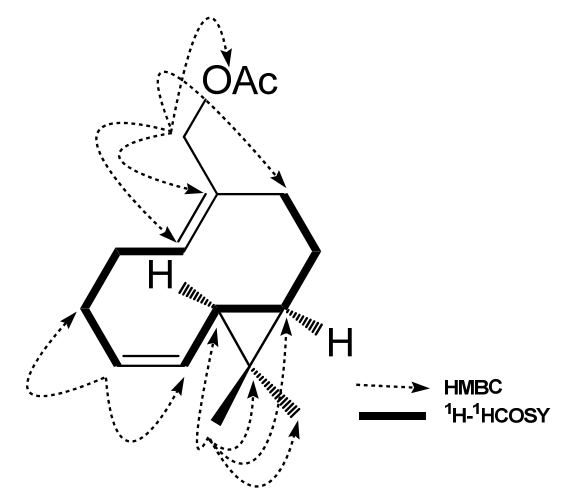

From the above data, the structure of $\mathbf{3}$ was identified as 15-acetoxy-4-carboxy-11, 11-dimethyl-bicyclogermacren- $4 E$ (5), 10Z (1)-diene, and it compound was named Volvalerenic acid D.

The five known compounds were identified as madolin A (4) and B (7) [26], vovalerenal A (6) and B (5) [18] and heishuixiecaoline B (8) [13] by comparing their NMR spectroscopic data with the literature values. The structures of compounds 1-8 are shown in Figure 5. 
Figure 5. The structures of compounds 1-8.
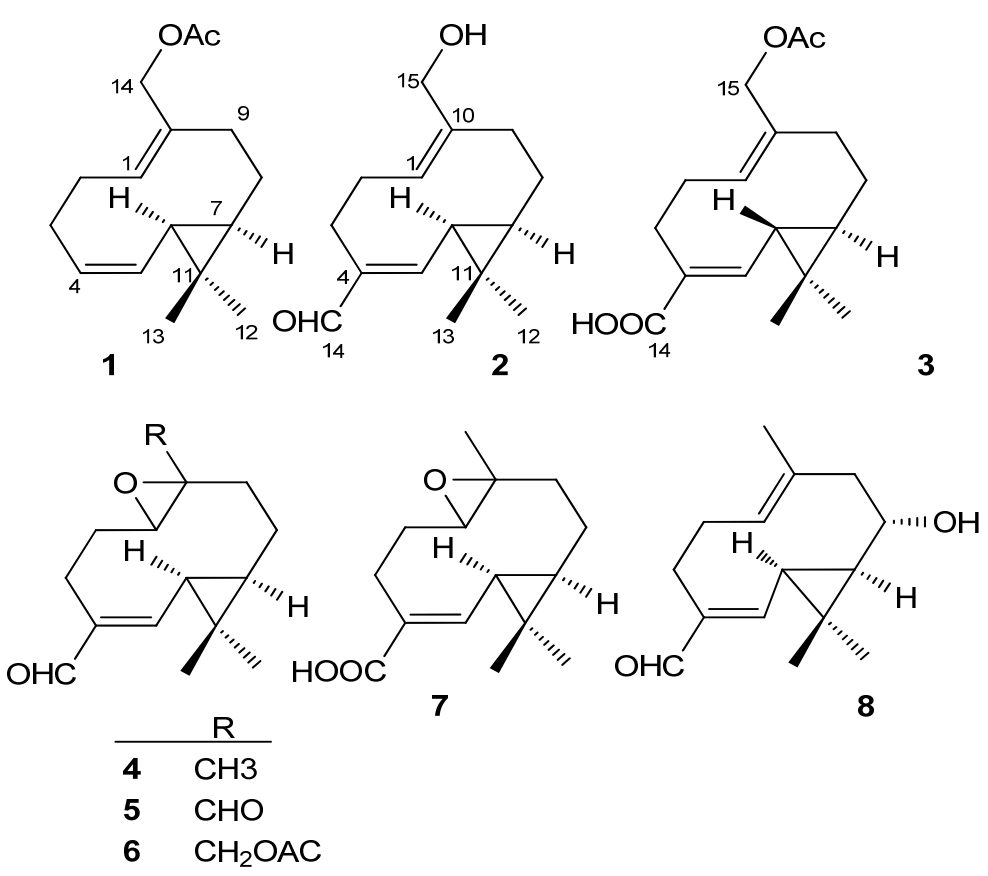

The propensity of compounds $\mathbf{1}-\mathbf{8}$ to enhance the activity on nerve growth factor (NGF)-mediated neurite outgrowth in PC 12D cells was assessed as described previously [25]. The neurite-bearing cells accounted for $22.74 \%$ and $100 \%$ in the control experiments incubated with 2 and $50 \mathrm{ng} / \mathrm{mL}$ NGF after $48 \mathrm{~h}$, respectively.

Under $2 \mathrm{ng} / \mathrm{mL}$ NGF conditions, all eight tested compounds (at 10, 30, $100 \mu \mathrm{mol}$ ) showed NGF-potentiating activities in various levels. Compound 3 (at $100 \mu \mathrm{mol}$ ) reached $50.15 \%$, in particular (Table 2).

Table 2. Effects of compounds 1-8 on the proportion of neurite-bearing PC 12D cells in the presence of NGF.

\begin{tabular}{|c|c|c|c|c|}
\hline \multirow{2}{*}{ Compound } & \multirow{2}{*}{ NGF(ng/mL) } & \multicolumn{3}{|c|}{ Cell viability (\%) } \\
\hline & & $10 \mu \mathrm{mol}$ & $30 \mu \mathrm{mol}$ & $100 \mu \mathrm{mol}$ \\
\hline 1 & 2 & $24.85 \pm 0.98$ & $33.97 \pm 1.77^{b}$ & $43.61 \pm 2.11^{\mathrm{c}}$ \\
\hline 2 & 2 & $24.42 \pm 1.12$ & $35.34 \pm 1.48^{b}$ & $44.30 \pm 1.85^{\mathrm{c}}$ \\
\hline 3 & 2 & $26.48 \pm 0.89^{\mathrm{a}}$ & $37.51 \pm 1.66^{\mathrm{b}}$ & $50.15 \pm 2.23^{c}$ \\
\hline 4 & 2 & $23.50 \pm 1.26$ & $29.33 \pm 0.88^{b}$ & $33.87 \pm 1.63^{c}$ \\
\hline 5 & 2 & $24.37 \pm 1.01$ & $30.12 \pm 1.97^{\mathrm{b}}$ & $40.79 \pm 1.17^{\mathrm{c}}$ \\
\hline 6 & 2 & $24.74 \pm 1.47$ & $34.84 \pm 2.35^{b}$ & $44.15 \pm 2.19^{c}$ \\
\hline 7 & 2 & $24.45 \pm 1.01$ & $33.96 \pm 1.13^{b}$ & $46.69 \pm 2.14^{c}$ \\
\hline \multirow[t]{4}{*}{8} & 2 & $24.26 \pm 0.73$ & $33.79 \pm 1.17^{\mathrm{b}}$ & $49.25 \pm 1.25^{\mathrm{c}}$ \\
\hline & 2 & & $23.08 \% \pm 1.28$ & \\
\hline & 50 & & $100 \%$ & \\
\hline & 0 & & $3.12 \% \pm 0.88$ & \\
\hline
\end{tabular}

Results expressed as mean \pm SD $(n=6)$ of eight independent experiments. The $100 \%$ value was obtained from $50 \mathrm{ng} / \mathrm{mL}$ NGF in the absence of compounds. A statistically significant difference $(\mathrm{a}, \mathrm{b}$ and $\mathrm{c}, p<0.01)$ from the control ( $2 \mathrm{ng} / \mathrm{mL} \mathrm{NGF)}$ in the absence of compounds was apparent. 


\section{Experimental}

\subsection{General}

Optical rotations were measured with a Perkin-Elmer 343 polarimeter (Perkin-Elmer, Waltham, MA, USA). IR spectra were recorded on the Bio-Rad FTS-65A spectrometer (Bio-Rad, Richmond, VA, USA). UV spectra were recorded using the UV-2501PC spectromter (Shimadzu, Japan). ${ }^{1} \mathrm{H}$ and ${ }^{13} \mathrm{C}-\mathrm{NMR}$ spectra were obtained on a JNM-ECS400 MHz spectrometer (JEOL, Tokyo, Japan) and a Varian UNITY INOVA 600 spectrometer (Varian, Palo Alto, CA, USA), and the chemical shifts were given on $\delta(\mathrm{ppm})$ scale with TMS as an internal standard. The HR-ESI-MS were recorded on a 9.4-TQ-FT-MS Apex Qe (Bruker Co., Billerica, MA, USA). Silica gel (60-120 mesh, 200-300 mesh, Qingdao Marine Chemical Group Co., Qingdao, China), and Sephadex LH-20 (Pharmacia, Uppsala, Sweden) were employed for column chromatography. HPLC was carried out using Waters 600E system (Waters, Milford, MA, USA): an analytical column, ODS $(5 \mu \mathrm{m}, 4.6 \times 250 \mathrm{~mm}$, Hanbon Science \& Technology Co., Ltd, Huaian, China), preparative column, a YMC C18 (5 $\mu \mathrm{m}, 20.0 \times 250 \mathrm{~mm}$, YMC, Kyoto, Japan), detector, Alltech ELSD (evaporative lightscattering detector, Alltech, Los Angeles, CA, USA) 2000ES. Flash chromatography was carried out on Teledyne ISCO Combi Flash $R f$ with Prepacked 80 g silica gel (200-300 mesh) columns (Teledyne Isco, Lincoln, NE, USA). TLC was carried out using silica gel 60 (>230 mesh, Qingdao Marine Chemical Group Co.) and GF254 plates precoated with silica gel 60. Spots on TLC were visually observed under UV light and/or by spraying with anisaldehyde- $\mathrm{H}_{2} \mathrm{SO}_{4}$ reagent followed by heating.

\subsection{Plant Material}

The dry roots of $V$. officinalis var. latifolia were collected from the Jiangkou region of Guizhou Province, China, in April 2012. The plant was identified by Prof. Bin Li (Beijing Institute of Radiation Medicine), and a voucher specimen (KYXC-20120313) is deposited in the herbarium of the Beijing Institute of Radiation Medicine, Beijing, China.

\subsection{Extraction and Isolation}

The air-dried roots of $V$. officinalis var. latifolia $(50 \mathrm{~kg})$ were exhaustively refluxed three times with $60 \% \mathrm{EtOH}(400 \mathrm{~L})$ to give a residue $(11 \mathrm{~kg})$ after removal of solvent under reduced pressure. The EtOH extract was suspended in $\mathrm{H}_{2} \mathrm{O}$ and then partitioned successively with $\mathrm{CHCl}_{3}(3 \times 10 \mathrm{~L})$. The $\mathrm{CHCl}_{3}$ extract (152.2 g) was subjected to silica gel (200-300 mesh) column chromatography, eluted with petroleum ether-acetone (from 100:1, 75:1, 50:1, 30:1, 25:1, 20:1, 15:1, 10:1, 7:1, 5:1, 3:1, 2:1 and 1:1, v/v) to afford thirteen fractions (A-M). Fraction E (4.711 g) was subjected to flash silica gel chromatography column (80 gram flash column, $60 \mathrm{~m} \mathrm{~L} / \mathrm{min}$ ) with $\mathrm{CHCl}_{3} / \mathrm{CH}_{3} \mathrm{OH}$ (from 50:1 to 10:1) to yield eight fractions, E1-E8. Fractions E2-E3 (0.225g) was chromatographed by Sephadex LH-20 $(2 \times 120 \mathrm{~cm}$, $\left.\mathrm{CHCl}_{3} / \mathrm{CH}_{3} \mathrm{OH}, 1: 1\right)$ to obtain compound 1 (33 mg). Fractions E4-E7 (0.818 g) was subjected to flash silica gel chromatography (40 gram flash column, petroleum ether-acetone, 5:1, $30 \mathrm{~mL} / \mathrm{min}$ ) and purified by Sephadex LH-20 $\left(2 \times 120 \mathrm{~cm}, \mathrm{CHCl}_{3} / \mathrm{CH}_{3} \mathrm{OH}, 1: 1\right)$ to afford compound $6(86 \mathrm{mg})$. Compound $4(168 \mathrm{mg})$ was isolated from fration E8 by a series of repeated Sephadex LH-20 $(2 \times 150 \mathrm{~cm}$, $\left.\mathrm{CHCl}_{3}-\mathrm{CH}_{3} \mathrm{OH}, 1: 1\right)$ column chromatography fractionations. Fraction I (3.678 g) was separated 
chromatographically on flash silica gel column (80 gram flash column, $60 \mathrm{~mL} / \mathrm{min}$ ) with $\mathrm{CHCl}_{3} / \mathrm{CH}_{3} \mathrm{OH}$ (40:1 to $2: 1)$, and a total of 50 tubes $(15 \mathrm{~mL}$ each) were collected. Tubes 19-40 (2.245 g) were chromatographed by flash silica gel chromatography (40 gram flash column, petroleum ether-acetone, 4:1, $30 \mathrm{~mL} / \mathrm{min}$ ) to obtain compound 8 (tubes 10-13, $78 \mathrm{mg}$ ). Fraction J (6.366 g) was subjected to a series of purification steps using flash silica-gel column chromatography (80 gram flash column, $\mathrm{CHCl}_{3} / \mathrm{CH}_{3} \mathrm{OH}, 20: 1$ to $\left.1: 1,60 \mathrm{~mL} / \mathrm{min}\right)$ to give ten fractions $(\mathrm{J} 1-\mathrm{J} 8)$. Fraction $\mathrm{J} 2-\mathrm{J} 4(0.167 \mathrm{~g})$ was chromatographed by Sephadex LH-20 column chromatography $\left(2 \times 150 \mathrm{~cm}, \mathrm{CH}_{3} \mathrm{OH}\right)$, and purified by preparative HPLC $\left(\mathrm{CH}_{3} \mathrm{OH} / \mathrm{H}_{2} \mathrm{O}, 75: 25\right.$, flow rate: $\left.2.0 \mathrm{~mL} \cdot \mathrm{min}^{-1}\right)$ to afford compounds $2(68 \mathrm{mg})$ and 5 (35 mg). Compounds $3(31 \mathrm{mg})$ and $7(78 \mathrm{mg})$ were obtained from fraction J6-J8 (0.167 g) by preparative HPLC $\left(\mathrm{CH}_{3} \mathrm{OH}-\mathrm{H}_{2} \mathrm{O}, 50: 50\right.$, flow rate: $\left.2.0 \mathrm{~mL} \cdot \mathrm{min}^{-1}\right)$.

\subsection{Compound Characterization}

Volvalerenal $F$ (1): colorless oil. $[\alpha]_{\mathrm{D}}^{20}+20.0\left(\mathrm{c} 0.8, \mathrm{CHCl}_{3}\right) ; \mathrm{UV}\left(\mathrm{CHCl}_{3}\right) \lambda_{\max } 237 \mathrm{~nm}$; IR (film) $v_{\max }$ 3445, 3171, 2960, 2924, 2852, 1730, 1627, 1261, 1095, $1024 \mathrm{~cm}^{-1}$; ${ }^{1} \mathrm{H}-\mathrm{NMR}\left(\mathrm{CHCl}_{3}, 600 \mathrm{MHz}\right)$ data, see Table 1; ${ }^{13} \mathrm{C}-\mathrm{NMR}\left(\mathrm{CHCl}_{3}, 150 \mathrm{MHz}\right)$ data, see Table 1; HR-ESI-MS $\mathrm{m} / z$ 271.1678 [M+Na $]^{+}$(calcd. for $\left.\mathrm{C}_{16} \mathrm{H}_{24} \mathrm{O}_{2} \mathrm{Na}, 271.1669\right)$.

Volvalerenal $G(2)$ : colorless oil. $[\alpha]_{\mathrm{D}}^{20}+53.9$ (c $\left.0.1, \mathrm{MeOH}\right)$; $\mathrm{UV}\left(\mathrm{CHCl}_{3}\right) \lambda_{\max } 264 \mathrm{~nm}$; IR (film) $v_{\max } 3382$, 2933, 2864, 1618, 1298, 1190, 1072, 921, $793 \mathrm{~cm}^{-1}$; ${ }^{1} \mathrm{H}-\mathrm{NMR}\left(\mathrm{CHCl}_{3}, 600 \mathrm{MHz}\right)$ data, see Table $1 ;{ }^{13} \mathrm{C}-\mathrm{NMR}$ $\left(\mathrm{CHCl}_{3}, 150 \mathrm{MHz}\right)$ data, see Table 1; HR-ESI-MS $m / z 235.1696[\mathrm{M}+\mathrm{H}]^{+}$(calcd. for $\mathrm{C}_{15} \mathrm{H}_{23} \mathrm{O}_{2}, 235.1693$ ).

Volvalerenic Acid D (3): colorless oil. $[\alpha]_{\mathrm{D}}^{20}+8.5$ (c 0.47, $\left.\mathrm{MeOH}\right) ; \mathrm{UV}\left(\mathrm{CHCl}_{3}\right) \lambda_{\max } 240$ and $271 \mathrm{~nm}$; IR (film) $v_{\max } 3384,3245,2931,2862,1238,1118,1027,862,768 \mathrm{~cm}^{-1}$; ${ }^{1} \mathrm{H}-\mathrm{NMR}\left(\mathrm{CHCl}_{3}, 600 \mathrm{MHz}\right)$ data, see Table $1 ;{ }^{13} \mathrm{C}-\mathrm{NMR}\left(\mathrm{CHCl}_{3}, 150 \mathrm{MHz}\right)$ data, see Table 1; HR-ESI-MS $m / z 293.1744[\mathrm{M}+\mathrm{H}]^{+}$(calcd. for $\left.\mathrm{C}_{17} \mathrm{H}_{25} \mathrm{O}_{2}, 293.1747\right)$.

\subsection{Activity Screening in Vitro}

PC 12D cell line was obtained from Insitute of Biochemistry and Cell Biology, CAS. It was cultured in Dulbecco's modified Eagles Medium (DMEM, Gibco, New York, NY, USA) with 10\% fetal calf serum (Gibco, New York, NY, USA), and 5\% equine serum (Gibco), and then the cells were maintained at $37.0^{\circ} \mathrm{C}$ in a humidified atmosphere which contained $6 \% \mathrm{CO}_{2}$ [25]. The test cell line was seeded in 24 -well culture paltes $\left(2 \times 10^{4}\right.$ cells/well) coated with poly-L-lysine (Gibco). After $24 \mathrm{~h}$, the medium was changed to test medium containing $1 \%$ fetal calf serum, $2 \%$ equine serum and varying concentrations of NGF (50 ng/mL for positive control, $2 \mathrm{ng} / \mathrm{mL}$ for test samples and significant difference control, Sigma, St. Louis, MO, USA) and test compounds 1-8 (10, 30, $100 \mu \mathrm{mol})$. After incubating for $48 \mathrm{~h}$, the cells were fixed with $1 \%$ glutaraldehyde (Sigma) in phosphate buffer, and the cells with neurites outgrowth were counted (with at least 100 cells examined/viewing area, three viewing areas/well, six wells/sample). The ratio of the neurite-bearing cells to total cells was determined and expressed as a percentage.

\section{Conclusions}

Three new germacrane-type sesquiterpenoids, volvalerenal F (1), volvalerenal G (2) and volvalerenic acid D (3), along with five known compounds 4-8, were isolated from the $\mathrm{CHCl}_{3}$ soluble partition of the 
ethanol extract of Valeriana officinalis var. latiofolia. NGF plays a key role in the functions of the central and peripheral nervous system [29] and all the sesquiterpenoids obtained displayed certain NGF-potentiating activities. From the current investigation it can be predicted that sesquiterpenoids will be promising candidates for dietary supplements and medicines, although further studies are needed to determine the pharmacological activities and the mechanism of these eight compounds in animals.

\section{Acknowledgments}

We are grateful to Yan Xue, Mei-feng Xu and Yu-mei Zhao of the National Center of Biomedical Analysis for the measurements of the MS and NMR spectra.

\section{Conflicts of Interest}

The authors declare no conflict of interest.

\section{References}

1. Chen, H.B.; Cheng, J.R. Taxonomic revision of the relative species of Valeriana officinalis Linn. from China. Bull. Bot. Res. 1991, 3, 29-40.

2. Chen, H.B.; Cheng, J.R. Studies on the Medicinal Plants of Valerianaceae in China. China J. Chin. Mater. Med. 1994, 2, 67-70.

3. Houghton, P.J. The biological activity of valerian and related plants. J. Ethnopharmacol. 1988, 22, 121-142.

4. Houghton, P.J. The scientific basis for the reputed activity of Valerian. J. Pharm. Pharmacol. 1999, 51, 505-512.

5. Valeriana officinalis (monograph). Altern. Med. Rev. 2004, 9, 438-441. Available online: http://www.thorne.com/altmedrev/.fulltext/9/4/438.pdf (accessed on 14 November 2003).

6. Thies, P.W. Zur Konstitution der isovalerian saureester Valepotriat, Acetoxyvalepotriat und Dihydrovalepotriat. Tetrahedron Lett. 1966, 11, 1163-1170.

7. Hendriks, H.; Geertsma, H.J.; Malingre, T.M. The occurrence of valeranone and crytofauronol in the essential oil of Valeriana officinalis cinalis L. collected in the northern part of the Netherlands. Pharm. Weekbl. 1981, 116, 1316-1320.

8. Leathwood, P.D.; Chauffard, F.; Heck, E.; Munoz-Box, R. Aqueous extract of valerian root (Valeriana officinalis L.) improves sleep quality in man. Pharmacol. Biochem. Behav. 1982, 1, 65-71.

9. Sakamoto, T.; Mltani, Y.; Nakajima, K. Psychotropic effects of Japanese Valerian Root extract. Chem. Pharm. Bull. 1992, 3, 758-761.

10. Santos, M.S.; Ferreira, F.; Faro, C.; Pires, E.; Carvalho, A.P.; Cunha, A.P.; Macedo, T. The amount of GABA Present in aqueous extracts of valerian is sufficient to account for $\left[{ }^{3} \mathrm{H}\right]$ GABA release in synaptosomes. Planta Med. 1994, 5, 475-476.

11. Zhang, Z.X.; Yao, X.S. The Advance of Chemical Study on the Medicinal Plant Valeriana officinalis L. Chin. J. Med. Chem. 2000, 3, 226-229.

12. Liu, X.G.; Gao, P.Y.; Wang, G.S.; Song, S.J.; Li, L.Z.; Li, X.; Yao, X.S.; Zhang, Z.X. In vivo antidepressant activity of sesquiterpenes from the roots of Valeriana fauriei Briq. Fitoterapia $\mathbf{2 0 1 2}$, 3, 599-603. 
13. Wang, Q.H.; Wang, C.F.; Zuo, Y.M.; Wang, Z.B.; Yang, B.Y.; Kuang, H.X. Compounds from the roots and rhizomes of Valeriana amurensis protect against neurotoxicity in PC12 cells. Molecules 2012, 12, 15013-15021.

14. Letchamo, W.; Ward, W.; Heard, B.; Heard, D. Essential oil of Valeriana officinalis L. cultivars and their antimicrobial activity as influenced by harvesting time under commercial organic cultivation. J. Agric. Food Chem. 2004, 12, 3915-3919.

15. Huang, B.K.; Qin, L.P.; Chu, Q.C.; Zhang, Q.Y.; Gao, L.H.; Zheng, H.C. Comparison of headspace spme with hydrodistillation and sfe for analysis of the volatile components of the roots of Valeriana officinalis var. latifolia. Chromatographia 2009, 69, 489-496.

16. Zhou, Y.; Fang, Y.; Gong, Z.F.; Duan, X.Y.; Liu, Y.W. Two New Terpenoids from Valeriana officinalis. Chin. J. Nat. Med. 2009, 72, 270-273.

17. Wang, P.C.; Hu, J.M.; Ran, X.H.; Chen, Z.Q.; Jiang, H.Z.; Liu, Y.Q.; Zhou, J.; Zhao, Y.X. Iridoids and sesquiterpenoids from the roots of Valeriana officinalis. J. Nat. Prod. 2009, 72, 1682-1685.

18. Wang, P.C.; Ran, X.H.; Chen, R.; Luo, H.R.; Liu, Y.Q.; Zhou, J.; Zhao, Y.X. Germacranetype sesquiterpenoids from the roots of Valeriana officinalis var. latifolia. J. Nat. Prod. 2010, 73, 1563-1567.

19. Wang, P.C.; Ran, X.H.; Luo, H.R.; Hu, J.M.; Chen, R.; Ma, Q.Y.; Dai, H.F.; Liu, Y.Q.; Xie, M.J.; Zhou, J. Volvalerelactones $\mathrm{A}$ and $\mathrm{B}$, two new sesquiterpenoid lactones with an unprecedented skeleton from Valeriana officinalis var. latifolia. Org. Lett. 2011, 12, 3036-3039.

20. Han, Z.Z.; Yan, Z.H.; Liu, Q.X.; Hu, X.Q.; Ye, J.; Li, H.L.; Zhang, W.D. Acylated iridoids from the roots of Valeriana officinalis var. latifolia. Planta Med. 2012, 15, 1645-1650.

21. Muller, N.F.; Dessing, R.P. European Society of Chemical Pharmacy. In Europaea Drug Index, 2nd ed.; Elsevier: New York, NY, USA, 1992; p. 1260.

22. $\mathrm{Xu}, \mathrm{L}$. United States Pharmacopeia/National Formulary(24): Valerian. World Phytomed. World Notes Plant Med. 2002, 3, 126-127.

23. Blumenthal, M. Herbs continue slide in mainstream market: Sales down 14 percent. Herbal. Gram. 2003, 58, 71 .

24. Flora of China Editorial Committee of Chinese Academy of Sciences. Flora Repubulicae Popularis Sinicae; Science Press: Beijing, China, 1986; Volume 1, pp. 32-34.

25. Wang, Y.W.; Chen, Q. The survey of medicinal efficacy of the Valeriana officinalis Linn. var. latifolia miq. of China. Asia Pac. Tradit. Med. 2005, 3, 69-71.

26. Wu, T.S.; Chan, Y.Y.; Leu, Y.L. Sesquiterpenes from the root and stem of Aristolochia cucurbitafolia. J. Nat. Prod. 1998, 4, 511-544.

27. Wu, T.S.; Leu, Y.L.; Chan, Y.Y. Constituents from the stem and root of Aristolochia kaempferi. Biol. Pharm. Bull. 2000, 10, 1216-1219.

28. Guo, Y.Q.; Xu, J.; Li, Y.S.; Yamakuni, T.; Ohizumi, Y. Three-membered ring sesquiterpenoids with NGF-potentiating activity from the roots of Valeriana fauriei. Planta Med. 2006, 4, 373-375.

29. Huang, E.J.; Reichardt, L.F. Trk receptors: Roles in neuronal signal transduction. Annu. Rev. Biochem. 2003, 72, 609-642.

Sample Availability: Samples of the compounds 1-8 are available from the authors.

(C) 2013 by the authors; licensee MDPI, Basel, Switzerland. This article is an open access article distributed under the terms and conditions of the Creative Commons Attribution license (http://creativecommons.org/licenses/by/3.0/). 